\section{Stand Establishment and Yield Potential of Organically Grown Seeded and Transplanted Medicinal Herbs}

\author{
Kathryn M. Kleitz ${ }^{1,6}$, Marisa M. Wall ${ }^{2,7}$, Constance L. Falk ${ }^{3}$, \\ Charles A. Martin ${ }^{4}$, Marta D. Remmenga ${ }^{5}$, and Steven J. Guldan ${ }^{4,8}$
}

AdDitional INDEX wORDs. Calendula officinalis, Nepeta cataria, Melissa officinalis, Urtica dioica, Sphaeralcea, calendula, catnip, lemon balm, stinging nettle, globemallow

Summary. Field studies were conducted in 1995 and 1996 at Las Cruces, New Mexico, and Alcalde, New Mexico, to compare direct seeding to transplanting for stand establishment and yield estimates of calendula (Calendula officinalis), catnip (Nepeta cataria), lemon balm (Melissa officinalis), stinging nettle (Urtica dioica), and globemallow (Sphaeralcea spp.). Calendula established well from seed or transplants at both sites. Transplanting increased establishment of lemon balm, catnip, stinging nettle, and globemallow. Lemon balm establishment was increased by $230 \%$ to $400 \%$ at Las Cruces, and catnip establishment was increased by $84 \%$ to $100 \%$ at Alcalde by transplanting. Direct seeding resulted in little or no stand establishment for stinging nettle and globemallow at Alcalde. In 1996, transplants increased lemon balm and stinging nettle dry weight yields by a factor of three or more at both sites. Dry weight yields of transplanted catnip were $4.86 \mathrm{t} \cdot \mathrm{ha}^{-1}$ in 1995 and $7.90 \mathrm{t} \cdot \mathrm{ha}^{-1}$ in 1996 in Las Cruces. Alcalde yields for transplanted dried catnip were $2.43 \mathrm{t} \cdot \mathrm{ha}^{-1}$ in 1995 and $5.12 \mathrm{t} \cdot \mathrm{ha}^{-1}$ in 1996. Transplanted globemallow dry weight yields were $6.04 \mathrm{t} \cdot \mathrm{ha}^{-1}$ in 1995 and $9.17 \mathrm{t} \cdot \mathrm{ha}^{-1}$ in 1996 for Las Cruces. Transplanted stinging nettle yield in Alcalde was $5.91 \mathrm{t} \cdot \mathrm{ha}^{-1}$ for plants that overwintered and were harvested in the second season. Transplanting versus direct seeding medicinal herbs has the potential to substantially increase stand establishment and yield in New Mexico, particularly in the more northern and cooler part of the state.

$\mathrm{T}$ he daily use of herbs by people throughout the world is common and widespread. From spices in foods and as herbal tea beverages to the substitution of

This research was supported by the New Mexico Agricultural Experiment Station, New Mexico State University, Las Cruces, and the USDA Agricultural Marketing Service, Federal-State Marketing Improvement Grant program. Use of trade names does not imply endorsement of the products named nor criticism of similar ones not named

${ }^{1}$ Department of Plant and Environmental Sciences, New Mexico State University, Las Cruces, NM 88003-8003

${ }^{2}$ Department of Plant and Environmental Sciences (formerly Agronomy and Horticulture), New Mexico State University, Las Cruces, NM 88003-8003

${ }^{3}$ Department of Agricultural Economics and Agricultural Business, New Mexico State University, Las Cruces, NM 88003-8003

${ }^{4}$ Alcalde Sustainable Agriculture Science Center, New Mexico State University, Las Cruces, NM 880038003

${ }^{5}$ University Statistics Center, New Mexico State University, Las Cruces, NM 88003-8003

${ }^{6}$ Present address: 5820 Agave Lane, Las Cruces, NM 88012

${ }^{7}$ Present address: U.S. Pacific Basin Agricultural Research Center, USDA-ARS, 64 Nowelo Street, Hilo, Hawaii 96720

${ }^{8}$ Corresponding author. E-mail: sguldan@nmsu.edu. pharmaceuticals with herbal compounds to treat illnesses, virtually everyone has used herbs in one manner or another. The total sales of herbal dietary supplements have shown growth in eight out of 10 years from 1996 to 2005 , including a $3.4 \%$ increase from 2003 to 2004 and a $2.1 \%$ increase from 2004 to 2005 (Blumenthal et al., 2006).

In New Mexico, commercial-size farms are being fragmented, and as the urban sector encroaches on rural areas in the irrigated valleys, highervalue alternative crops are being sought. Small-scale farms cannot successfully compete in commercial commodity markets. New Mexico encompasses a range of climatic zones, and many medicinal plants that are in demand could be grown in the state. If production practices could be determined, many farms could supplement the production of agronomic and vegetable crops with herb cultivation (Falk et al., 1996). Diseases in current crops such as chile peppers (Capsicum annuum) could be reduced with alternate crops that may not serve as hosts to the pathogens. Thus, the cultivation of medicinal herbs on small New Mexico farms could be an important avenue for economic development in rural areas (Miller, 1985).

We selected medicinal herbs to include in field studies in southern and northern New Mexico based on a national market survey conducted by New Mexico State University in which participants in the study indicated that these herbs were used regularly and that they were looking for new sources (Falk et al., 1996). These herbs included calendula, catnip, lemon balm, stinging nettle, and globemallow.

Calendula is an annual, whereas catnip, lemon balm, stinging nettle, and globemallow are generally considered perennials, depending on where they are grown. Traditional uses of these medicinal herbs vary. Calendula flowers are used in topical applications for minor skin ailments and burns (Ody, 1993). An infusion made from flowers is useful for treating mouth ulcers and gum disease (Tyler, 1994). Catnip has general antimicrobial properties (Angelini et al., 2006; Bourrel et al., 1993) and is used as a tea to relieve headaches, stomach aches, anxiety, and sleep disorders (Cauffield and Forbes, 1999; Foster, 1993). Lemon balm tea or tincture also acts as a mild sedative and relieves digestive upsets (Kennedy et al., 2006; Muller and Klement, 2006; Ody, 1993). Lemon balm oil has antibacterial,

\begin{tabular}{llll}
\hline $\begin{array}{l}\text { Units } \\
\begin{array}{l}\text { To convert U.S. to SI, } \\
\text { multiply by }\end{array}\end{array}$ & U.S. unit & Sl unit & $\begin{array}{l}\text { To convert SI to U.S., } \\
\text { multiply by }\end{array}$ \\
\hline 7.8125 & $\mathrm{fl} \mathrm{oz} / \mathrm{gal}$ & $\mathrm{mL} \cdot \mathrm{L}^{-1}$ & 0.1280 \\
0.3048 & $\mathrm{ft}$ & $\mathrm{m}$ & 3.2808 \\
0.0929 & $\mathrm{ft}^{2}$ & $\mathrm{~m}^{2}$ & 10.7639 \\
2.54 & inch $(\mathrm{es})$ & $\mathrm{cm}$ & 0.3937 \\
0.4536 & $\mathrm{lb}$ & $\mathrm{kg}$ & 2.2046 \\
2.2417 & ton/acre & $\mathrm{t} \cdot \mathrm{ha}^{-1}$ & 0.4461 \\
$\left({ }^{\circ} \mathrm{F}-32\right) \div 1.8$ & ${ }^{\circ} \mathrm{F}$ & ${ }^{\circ} \mathrm{C}$ & $\left(1.8 \times{ }^{\circ} \mathrm{C}\right)+32$
\end{tabular}


antioxidant, and antitumor properties (de Sousa et al., 2004), and creams are used in Europe for the treatment of herpes simplex virus (Koytchev et al., 1999; Tyler, 1994). Stinging nettle leaf modulates the immune system and is helpful in treating arthritis, rheumatism, and diabetes (Akbay et al., 2003; Ody, 1993). Leaf extracts increase insulin secretion, and have analgesic, antioxidant, and antimicrobial activity (Farzami et al., 2003; Gulcin et al., 2004). Clinical studies showed that stinging nettle root provided relief for prostate enlargement (Belaiche and Lievoux, 1991). Globemallow has been used to soothe sore throats and irritable stomachs (Moore, 1979), and has been included in hair rinses and shampoos to give the hair body, condition, and shine (Moore, 1990).

Although countless books on herb gardening have been written, few of them provide the detailed information necessary to grow herbs on a commercial scale. When comprehensive information is found, it usually pertains to growing regions not applicable to the Southwest (Galambosi, 1993; Starman et al., 1995; Sturdivant, 1994). Field establishment of plants can be challenging in New Mexico soils. The soil is typically alkaline, often forming a crust that is difficult for tender seedlings to penetrate (Doolittle and Tiedebohl, 1953). Studies are needed to determine the most efficient method of establishment for the cultivation of medicinal herbs. The purpose of this study was to compare direct seeding to transplants for plant establishment, and to find the number of marketable harvests and the yield for five herbs: calendula, catnip, lemon balm, stinging nettle, and globemallow.

\section{Materials and methods}

Field studies were conducted in 1995 and 1996 in Las Cruces and Alcalde, New Mexico. Las Cruces and Alcalde were chosen to evaluate the herbs under growing conditions in the southern and northern parts of the state, respectively. The Fabian Garcia Science Center in Las Cruces (lat. $32^{\circ} \mathrm{N}$, long. $106^{\circ} \mathrm{W}$, elevation $3890 \mathrm{ft}$ ) has an average of 220 frostfree days per year (Herrera, 1989), and is in climate zone 8 (U.S. National Arboretum, 2003). Trials were conducted on a Glendale loam [fine-silty, mixed (calcareous), thermic Typic Torrifluvent] with a $\mathrm{pH}$ of 7.8. Fresh dairy cow manure was incorporated into the soil at a rate of $8.0 \mathrm{t} \cdot \mathrm{ha}^{-1}$ in Fall 1994. The Alcalde Sustainable Agriculture Science Center (lat. $36^{\circ} \mathrm{N}$, long. $106^{\circ} \mathrm{W}$, elevation $5720 \mathrm{ft}$ ) averages 152 frost-free days per year (New Mexico State University, 1998), and is in climate zone 6 (U.S. National Arboretum, 2003). Trials were conducted on a Fruitland sandy loam [coarse-loamy, mixed (calcareous), mesic Typic Torriorthent] with a $\mathrm{pH}$ of 7.5 that had a previous crop of alfalfa (Medicago sativa).

All transplants were produced in a greenhouse at the Fabian Garcia Agricultural Science Center. In 1995 , seeds were sown in germination trays using Premier Promix media (Premier Horticulture Ltd., Steinbach, Canada) in early March for the Las Cruces site and in late March for Alcalde. In 1996, slightly larger germination trays were used and the seeds were initiated in mid-February for Las Cruces and in mid-March for Alcalde. Catnip, lemon balm, stinging nettle, and calendula seeds were purchased from Richters (Ontario, Canada), and globemallow seeds were purchased from Plants of the Southwest (Santa Fe, NM).

Seedlings were watered twice daily and fertilized once per week starting when the seedlings were about 3 weeks old. The fertilizer was a liquid fish fertilizer $(5 \mathrm{~N}-0.4 \mathrm{P}-$ $0.8 \mathrm{~K}$; Alaska Fish Fertilizer Co., Renton, WA) and was applied as a diluted solution ( $1 \mathrm{fl} \mathrm{oz} / \mathrm{gal}$ ). Plants were grown for about 7 weeks before they were hardened off by placing them in a lath house ( $50 \%$ shade) for 1 week, followed by transplanting them into the field. Plants in directseeded plots were thinned to the same density as transplants at each site.

A randomized complete block design with four blocks was used for field trials. In Las Cruces, border plants of firewheel (Gaillardia pulchella) were planted between each block. The plots measured $15 \mathrm{ft}$ long and $3 \mathrm{ft}$ wide. Each plot contained two rows of plants with border plants at the end of each row. The in-row plant spacing for the herbs was $1 \mathrm{ft}$, and 20 plants were harvested in an area of $30 \mathrm{ft}^{2}$ for each treatment. The beds were mulched with pecan shells to reduce water loss and weed growth. The shells were obtained from a local pecan processing plant and were applied to create a surface mulch layer $\approx 2$ inches deep. Weeding was done by hand on a weekly basis, as needed. The herbs were watered by drip irrigation as needed. In 1995, weekly foliar applications of fish fertilizer (using the same formulation as applied to seedlings in the greenhouse) were applied to the plants until the surfaces of aerial portions were saturated and began to drip. The experiment was repeated in 1996 on the same plots after 1995 plants were removed.

In Alcalde, furrow irrigation was used on single-row beds formed on 3 - $\mathrm{ft}$ centers. Each plot contained two beds that measured a total of $15 \times 6 \mathrm{ft}$. Border plants were planted at the ends of each bed. In each plot, 20 plants were harvested from a $60-\mathrm{ft}^{2}$ area. Weeding was accomplished by using a tractor-drawn rolling-tine cultivator early in the season and then hand-hoeing was performed as needed. Irrigation was done as needed, which was every week during establishment and every 2 or 3 weeks throughout the growing season, depending on precipitation. In 1996, this study was replicated in an area adjacent to the original study, giving 2 years of first-year yields. In addition, some plants established in 1995 overwintered and provided second-year yields in 1996.

At both sites in 1995, the plants were measured for height at about 2 -week intervals to monitor their growth. Border plants were not counted in the yields, and manual harvests were made throughout the growing season. Flowers were harvested from calendula, and leaves and stems were harvested from stinging nettle, catnip, lemon balm, and globemallow. Open calendula flowers were harvested by detaching the flower from the stem beneath the calyx. The vegetative parts were harvested from the other crops by cutting the plants' stems $\approx 4$ inches above the soil line. Calendula was harvested when $75 \%$ or more of plants had open flowers. Catnip, lemon balm, stinging nettle, and globemallow were harvested at bud to early flower stage. In general, all four blocks were harvested at each site when a harvest decision was made; 
in a few cases, an individual block was ahead or behind in growth. In Las Cruces, calendula flowers were airdried, in the dark, at ambient temperatures $\left(32\right.$ to $\left.35^{\circ} \mathrm{C}\right)$. The remaining herbs were dried in an oven at $38^{\circ} \mathrm{C}$ (Marcin, 1993).

In Alcalde, harvests were made using the same methods as described for the Las Cruces site. However, because of inadequate space to dry all the plant material, dry weights were determined from subsamples of the fresh harvest. At both sites, cultural growing practices were consistent with the guidelines for organic farming, as outlined in the organic certification program by the New Mexico Organic Commodity Commission (2003).

Data were analyzed as a randomized complete block design using the GLM procedure of SAS (version 6.11; SAS Institute, Cary, NC) for each species. Four replications were used, except for lemon balm at Alcalde in 1995, where three replications were planted.

\section{Results and discussion}

General observations. In 1995, crops in southern New Mexico were plagued with diseases vectored by leafhoppers (e.g., Circulifer spp., Empoasca spp., and Macrosteles spp.) because of the mild winter of 19941995. The herb field in Las Cruces was similarly affected. Leafhoppers are known vectors of the curly top virus and aster yellows (Pedigo, 1989). Leafhoppers attacked the calendula, causing mottling of the leaves and reduced plant growth. For both years, the calendula plants flowered continuously for almost 2 months. However, calendula typically begins flowering about 6 weeks after planting and continues until late autumn (Foster, 1993). After 2 months, flowering essentially stopped and the plants deteriorated, indicating that the southern New Mexico climate may be at the extreme zone that these plants can tolerate. Calendula grew well at Alcalde, and had no noticeable pest problems.

Catnip was also affected by the leafhoppers in Las Cruces, causing virus symptoms of severely stunted plant growth, chlorosis, and thickened leaves. At Alcalde, some of the catnip plants exhibited variegated yellowing consistent with virus infection, although plant growth was unaffected.

Lemon balm grew slowly in Las Cruces. The plants were small and they developed leaf burn on the undergrowth after harvests. At Alcalde, lemon balm was slow to establish through direct seeding and transplanting, but grew well once established. Stinging nettle grew slowly in the establishment year whether from direct seeding or transplants, particularly at Las Cruces. Globemallow, although showing weak germination in the greenhouse and when direct-seeded in the field, grew well at both sites once established.

Establishment. Across years, locations, and species, the stand establishment of transplants was significantly greater $74 \%$ of the time when compared to direct seeding (Table 1). In no case was percentage of stand establishment significantly lower by transplant than by direct seeding. In fact, transplants increased lemon balm establishment by $230 \%$ to $400 \%$ at Las Cruces, and catnip establishment by $84 \%$ to $100 \%$ at Alcalde, when compared to direct seeding.

Direct seeding resulted in limited stand establishment for stinging nettle

Table 1. Stand establishment of direct-seeded (S) and transplanted (T) medicinal herbs in southern (Las Cruces) and northern (Alcalde) New Mexico.

\begin{tabular}{|c|c|c|c|c|c|}
\hline \multirow[b]{3}{*}{ Crop } & \multirow[b]{3}{*}{ Treatment } & \multicolumn{4}{|c|}{ Stand (plants $/$ plot $)^{\mathrm{z}}$} \\
\hline & & \multicolumn{2}{|c|}{ Las Cruces } & \multicolumn{2}{|c|}{ Alcalde } \\
\hline & & 1995 & 1996 & 1995 & 1996 \\
\hline \multirow[t]{3}{*}{ Calendula } & $S^{y}$ & 20.0 & 16.3 & 20.0 & 19.0 \\
\hline & $\mathrm{T}^{\mathrm{x}}$ & 20.0 & 20.0 & 20.0 & 20.0 \\
\hline & & NS & * & NS & NS \\
\hline \multirow[t]{3}{*}{ Catnip } & $S$ & 15.8 & 11.5 & 10.5 & 10.0 \\
\hline & $\mathrm{T}$ & 20.0 & 19.3 & 19.3 & 20.0 \\
\hline & & * & NS & * & * \\
\hline \multirow[t]{3}{*}{ Lemon balm } & $S$ & 3.9 & 6.0 & 17.8 & 6.3 \\
\hline & $\mathrm{T}$ & 19.3 & 20.0 & 14.5 & 20.0 \\
\hline & & ** & *** & NS & ** \\
\hline \multirow[t]{3}{*}{ Stinging nettle } & $S$ & 13.8 & 0.5 & 1.3 & 0.0 \\
\hline & $\mathrm{T}$ & 19.0 & 19.8 & 19.0 & 20.0 \\
\hline & & ** & $* * *$ & $* * *$ & *** \\
\hline \multirow[t]{3}{*}{ Globemallow } & $S$ & 9.8 & 5.8 & 1.3 & 0.5 \\
\hline & $\mathrm{T}$ & 14.8 & 20.0 & 20.0 & 19.8 \\
\hline & & NS & ** & $* * *$ & $* * *$ \\
\hline
\end{tabular}

${ }^{2}$ Means are averages of four replications. At Las Cruces, harvested plot area $=30 \mathrm{ft}^{2}\left(2.8 \mathrm{~m}^{2}\right)$ and contained a maximum of 20 plants. At Alcalde, harvested plot area $=60 \mathrm{ft}^{2}\left(5.6 \mathrm{~m}^{2}\right)$ and contained a maximum of 20 plants. ${ }^{y}$ Direct-seeded plots. At Las Cruces, stand counts were recorded 72 d (9 June 1995) and 71 d (11 June 1996) after seeding. At Alcalde, stand counts were recorded 65 d (6 July 1995) and 55 d (26 June 1996) after seeding. ${ }^{x}$ Transplanted plots. At Las Cruces, stand counts were recorded $47 \mathrm{~d}$ (9 June 1995) and $56 \mathrm{~d}$ (11 June 1996) after transplanting. At Alcalde, stand counts were recorded $53 \mathrm{~d}$ (6 July 1995) and $41 \mathrm{~d}$ (26 June 1996) after transplanting.

NS,*,**,***Nonsignificant or significant at $P \leq 0.05,0.01$, or 0.001 , respectively. 
Table 2. Number of days from planting until first harvest and total number of harvests for direct-seeded (S) and transplanted (T) medicinal herbs grown in southern (Las Cruces) and northern (Alcalde) New Mexico.

\begin{tabular}{|c|c|c|c|c|c|c|c|c|c|}
\hline \multirow[b]{3}{*}{ Crop } & \multirow[b]{3}{*}{ Treatment } & \multicolumn{4}{|c|}{ Las Cruces } & \multicolumn{4}{|c|}{ Alcalde } \\
\hline & & \multicolumn{2}{|c|}{$\begin{array}{c}\text { Time until } \\
\text { first harvest }(\mathrm{d})^{\mathrm{z}}\end{array}$} & \multicolumn{2}{|c|}{$\begin{array}{l}\text { Total harvests } \\
\text { (no.) }\end{array}$} & \multicolumn{2}{|c|}{$\begin{array}{c}\text { Time until } \\
\text { first harvest }(\mathrm{d})^{\mathrm{z}}\end{array}$} & \multicolumn{2}{|c|}{$\begin{array}{c}\text { Total harvests } \\
{\text { (no. })^{\mathrm{y}}}^{\text {Tol }}\end{array}$} \\
\hline & & 1995 & 1996 & 1995 & 1996 & 1995 & 1996 & 1995 & 1996 \\
\hline \multirow[t]{2}{*}{ Calendula } & $S^{x}$ & 68 & 80 & 13.0 & 8.0 & 65 & 78 & 9.5 & 7.0 \\
\hline & $\mathrm{T}^{\mathrm{w}}$ & 45 & 66 & 12.5 & 7.5 & 51 & 64 & 10.0 & 7.0 \\
\hline Catnip & $S$ & 97 & 105 & 3.0 & 3.0 & 99 & 78 & 2.0 & 2.0 \\
\hline & $\mathrm{T}$ & 172 & 113 & 1.0 & 2.0 & 99 & 139 & 1.0 & 1.0 \\
\hline \multirow[t]{2}{*}{ Stinging nettle } & $S$ & 116 & 106 & 1.3 & 1.0 & 141 & 0 & 0.3 & 0 \\
\hline & $\mathrm{T}$ & 88 & 92 & 2.0 & 2.0 & 85 & 64 & 2.0 & 2.0 \\
\hline \multirow[t]{2}{*}{ Globemallow } & $S$ & 115 & 85 & 2.0 & 2.8 & 0 & 0 & 0 & 0 \\
\hline & $\mathrm{T}$ & 88 & 65 & 2.0 & 3.0 & 92 & 75 & 2.0 & 2.0 \\
\hline
\end{tabular}

${ }^{2}$ Number of days from planting until first harvest.

${ }^{y}$ Number of harvests are means of four replications.

'Direct-seeded plots.

wransplanted plots.

of lemon balm was made in 1995 at Las Cruces for both treatments (Table 2). In the second year, transplanted plots grew faster, allowing two harvests in the season. Conversely, at Alcalde, seeded lemon balm produced two harvests in 1995, whereas the transplanted plots produced one harvest. In 1996, both treatments produced only one harvest (Table 2).

At Las Cruces, stinging nettle produced about one harvest for seeded plots and an additional harvest for transplants. Transplanted stinging nettle were also harvested twice at Alcalde. However, for seeded stinging nettle, there was one harvest of one block in 1995, as the remaining seeded blocks did not germinate.

Globemallow was harvested two to three times, except for the seeded plots that did not germinate at Alcalde (Table 2). At Las Cruces in 1996, there was an additional harvest of globemallow that may have been due to small pieces of roots that remained in the soil after the first year. These pieces remained viable, and it is possible that the 1996 harvests partially contained material initiated in 1995.

GROWTH AND YIELDS. Dry weight yields for calendula flowers were similar from seed and from transplants in each location and year (Table 3). In 1995, however, plants grew about $20 \mathrm{~cm}$ taller (data not shown) and yields were three times greater in Alcalde than in Las Cruces. The impact of leafhopper-vectored

Table 3. Yield for direct-seeded (S) and transplanted $(\mathrm{T})$ medicinal herbs grown in southern (Las Cruces) and northern (Alcalde) New Mexico.

\begin{tabular}{|c|c|c|c|c|c|c|}
\hline \multirow[b]{3}{*}{ Crop } & \multirow[b]{3}{*}{ Treatment } & \multicolumn{5}{|c|}{ Dry wt $t^{\mathrm{z}}\left(\mathrm{t} \cdot \mathrm{ha}^{-1}\right)$} \\
\hline & & \multicolumn{2}{|c|}{ Las Cruces } & \multicolumn{3}{|c|}{ Alcalde } \\
\hline & & 1995 & 1996 & 1995 & S-1995 & 1996 \\
\hline \multirow[t]{3}{*}{ Calendula } & $S^{\mathrm{x}}$ & 0.25 & 0.41 & 0.77 & - & 0.46 \\
\hline & $\mathrm{T}^{\mathrm{w}}$ & 0.28 & 0.37 & 0.83 & 一 & 0.48 \\
\hline & & NS & NS & NS & & NS \\
\hline \multirow[t]{3}{*}{ Catnip } & $S$ & 5.65 & 4.63 & 1.01 & 6.60 & 3.75 \\
\hline & $\mathrm{T}$ & 4.86 & 7.90 & 2.43 & 10.37 & 5.12 \\
\hline & & NS & $* * *$ & * & ** & NS \\
\hline \multirow[t]{3}{*}{ Lemon balm } & $S$ & 0.18 & 1.27 & 1.03 & 0.80 & 0.49 \\
\hline & $\mathrm{T}$ & 2.35 & 3.91 & $0.28^{\mathrm{v}}$ & $2.63^{\mathrm{u}}$ & 2.18 \\
\hline & & * & ** & & & * \\
\hline \multirow[t]{3}{*}{ Stinging nettle } & $S$ & 0.54 & 0.04 & 0.03 & 0.34 & 0 \\
\hline & $\mathrm{T}$ & 1.18 & 2.07 & 0.81 & 5.91 & 2.10 \\
\hline & & * & * & * & $* * *$ & ** \\
\hline \multirow[t]{3}{*}{ Globemallow } & $S$ & 4.46 & 7.89 & 0 & 0 & 0 \\
\hline & $\mathrm{T}$ & 6.04 & 9.17 & 2.86 & 15.20 & 6.39 \\
\hline & & NS & NS & * & ** & $* * *$ \\
\hline
\end{tabular}

${ }^{\mathrm{z}}$ Means are averages of four replications; $\mathrm{lt} \cdot \mathrm{ha}^{-1}=0.446 \mathrm{t}$ ton/acre.

y Spring harvest of overwintered 1995 planting.

${ }^{x}$ Direct-seeded plots.

wTransplanted plots.

Mean of two replications.

"Single observation.

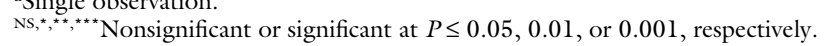

viruses in 1995 was evident in the Las Cruces calendula yields. Although more harvests were made in 1995 for calendula at Las Cruces, fewer, smaller flowers were harvested, and yields were not higher than in 1996 (Table 3). Given the added cost of initiating transplants in a greenhouse, these results indicate that calendula could be direct seeded in New Mexico.

Catnip plant heights reached about $29 \mathrm{~cm}$ for both establishment methods and locations. There were no differences in yield between seeded and transplanted plots in 1995 at Las Cruces and in 1996 at Alcalde. However, catnip transplants yielded $71 \%$ more dry weight than seeded plots in 1996 at Las Cruces, and $141 \%$ more in 1995 at Alcalde (Table 3 ).

Lemon balm grew to average heights of $22 \mathrm{~cm}$ (seeded) and $26 \mathrm{~cm}$ (transplants) at Las Cruces and $18 \mathrm{~cm}$ (seeded) and $15 \mathrm{~cm}$ (transplants) at 
Alcalde (data not shown). These plant heights are well below the $60-\mathrm{cm}$ heights reported by Foster (1993) for lemon balm grown in other areas of the country. Yields of lemon balm established by transplants were substantially greater than yields by direct seeding: three and 13 times greater at Las Cruces, and four times greater at Alcalde (Table 3).

Generally poor emergence of direct-seeded stinging nettle resulted in low or no yields for this treatment (Table 3). Transplant yields were similar between sites in a given year, but were higher overall in 1996. In the establishment year, plants did not grow taller than $30 \mathrm{~cm}$ in Las Cruces or $25 \mathrm{~cm}$ in Alcalde. In Las Cruces, they appeared stressed, small, and slightly wilted. Stinging nettle does not appear well-suited for the hot, dry summers and the alkaline soils with low organic matter that are common in the southwestern United States. In their native habitat, stinging nettle grow in damp, rich soil, often near streams, and reach from 60 to $180 \mathrm{~cm}$ in height (Foster, 1993).

At Alcalde, there was no yield for direct-seeded globemallow because of low establishment. In contrast, at Las Cruces, neither year showed significant differences in yield between the two establishment methods (Table 3). Therefore, direct seeding of this crop would be recommended for the Las Cruces area rather than using transplants. Globemallow grew taller than any of the herbs studied, reaching average heights of 90 and $105 \mathrm{~cm}$ in Las Cruces and Alcalde, respectively (data not shown). Once established, globemallow produced relatively high yields at both locations in both years. However, markets have not been developed for globemallow (Falk et al., 2000), therefore, supply could easily exceed demand.

AlCALDE SPRING HARVEST OF OVERWINTERED 1995 PLANTING. In the spring of 1996, harvests at Alcalde were taken from catnip, lemon balm, stinging nettle, and globemallow that overwintered from the 1995 growing season (Table 3). Except for lemon balm and direct-seeded plots with poor establishment, yields were higher from this second-year harvest compared to first year yields. Yields for transplanted catnip, stinging nettle, and globemallow were $103 \%$, $181 \%$, and $138 \%$ higher, respectively, than the highest first-year yield for that species.

Ferguson et al. (1988) estimated catnip yields of 4.4 to $6.7 \mathrm{t} \cdot \mathrm{ha}^{-1}$ under good growing conditions in North Carolina. Duppong et al. (2004) reported second-year catnip yields of 2.6 to $4.1 \mathrm{t} \cdot \mathrm{ha}^{-1}$ in a study evaluating the use of organic mulches. The Alcalde second-year yield from transplants was higher than yields in both reports.

Our stinging nettle results are consistent with a previous study in Germany (Heeger, 1956) in which plant development was slow for the first year. Weiss (1993) also reported slow growth of stinging nettle in the first year, with significant improvements in the second and third year. For globemallow, it is possible that the plants spread from the root or crowns and became prolific in the second year.

\section{Conclusions}

Based on our results, we recommend that calendula be direct seeded into New Mexico soils. However, profits are marginal because harvests are labor intensive and yields are low (Falk et al., 2000). If yields could be increased, perhaps through fall planting in southern New Mexico, higher plant densities, or enhanced fertility, then profitability could be increased. The strong germination potential of this herb keeps initial production costs low, making this plant an attractive crop for New Mexico farmers to grow. However, techniques need to be improved to make harvest more cost effective. The use of a mechanical rake, similar to one used for chamomile flowers, may reduce harvest labor costs for calendula flowers (Johnny's Selected Seeds, 2007).

Catnip seems to be well suited for New Mexico. Yields were high in both locations, particularly for transplants. In either case, whether from seed or transplants, catnip production could generate a positive economic return (Falk et al., 2000).

Lemon balm yields were modest in Las Cruces and Alcalde. However, transplanting increased yields substantially over direct seeding, allowing transplants to be grown profitably in both locations (Falk et al., 2000).

The climate in southern New Mexico may be too hot for cultivation of stinging nettle. However, cooler climates in northern New Mexico seem to facilitate growth of this herb, particularly as a perennial, as the second harvest season yielded about seven times more vegetative growth than the initial harvest in 1995 for transplants. Economic analysis showed a positive net return for transplanted stinging nettle only when production yields exceed $2.24 \mathrm{t} \cdot \mathrm{ha}^{-1}$ of dried leaf weight and the selling price was at least $\$ 6.62 / \mathrm{kg}$ (Falk et al., 2000). This yield level was exceeded only in the case of second-year production by transplants at Alcalde.

Globemallow grew well in both locations, although transplants were needed to grow this crop in northern New Mexico. Although the yields were high, the market for globemallow is not well established (Falk et al., 2000).

More research is needed on these plants to provide comprehensive production guidelines for New Mexico farmers. For example, studies need to be conducted to establish organic soil fertility strategies and optimum irrigation schedules that maximize medicinal herb yields. Currently, there are no guidelines governing these aspects of production.

Medicinal herbs have been and will continue to be used by various segments of the world's population. The native stands of these herbs cannot fill the demand, thus the necessity for commercial cultivation. Few farmers will attempt to grow these herbs until specific questions regarding production and marketing are answered. Although it is unlikely that medicinal herbs will be as commonplace as other crops in New Mexico and the southwestern United States, medicinal herbs can bring substantial economic returns and also improve the quality of life for rural communities.

\section{Literature cited}

Akbay, P., A.A. Basaran, U. Undeger, and N. Basaran. 2003. In vitro immunomodulatory activity of flavonoid glycosides from Urtica dioica L. Phytotherapy Res. 17:34-37.

Angelini, P., R. Pagiotti, A. Menghini, and B. Vianello. 2006. Antimicrobial activities of various essential oils against foodborne pathogenic or spoilage moulds. Ann. Microbiol. 56:65-69.

Belaiche, P. and O. Lievoux. 1991. Clinical studies on the palliative treatment of 
prostatic adenoma with extract of Urtica root. Phytotherapy Res. 5:267-269.

Blumenthal, M., G.K.L. Ferrier, and C. Cavaliere. 2006. Total sales of herbal supplements in United States show steady growth. HerbalGram 71:64-66.

Bourrel, C., F. Perineau, G. Michel, and J.M. Bessiere. 1993. Catnip (Nepeta cataria L.) essential oil: Analysis of chemical constituents, bacteriostatic and fungistatic properties. J. Essential Oil Res. 5:159-167.

Cauffield, J.S. and H.J. Forbes. 1999. Dietary supplements used in the treatment of depression, anxiety, and sleep disorders. Lippincotts Prim. Care Pract. 3:290-304.

de Sousa, A.C., D.S. Alviano, A.F. Blank, P. Barreto Alves, C.S. Alviano, and C.R. Gattass. 2004. Melissa officinalis L. essential oil: Antitumoral and antioxidant activities. J. Pharm. Pharmacol. 56:677-681.

Doolittle, R. and H. Tiedebohl. 1953. Southwest gardening. University of New Mexico Press, Albuquerque, NM.

Duppong, L.M., K. Delate, M. Liebman, R. Horton, F. Romero, G. Kraus, J. Petrich, and P.K. Chowdbury. 2004. The effect of natural mulches on crop performance, weed suppression and biochemical constituents of catnip and St. John's wort. Crop Sci. 44:861-869.

Falk, C.L., S. Meeks, and T. Enos. 1996. National market analysis for southwestern herbs. New Mexico Agr. Expt. Sta. Res. Rpt. 704.

Falk, C.L., H. van Voorthuizen, M.M. Wall, S.J. Guldan, C.A. Martin, and K.M. Kleitz. 2000. An economic analysis of transplanting versus direct seeding of selected medicinal herbs in New Mexico. J. Herbs Spices Medicinal Plants 7(4): 15-29.

Farzami, G., D. Ahmadvand, S. Vardasbi, F.J. Majin, and S. Khaghani. 2003. Induction of insulin secretion by a component of Urtica dioica leaf extract in perfused
Islets of Langerhans and its in vivo effects in normal and streptozotocin diabetic rats. J. Ethnopharmacol. 89:47-53.

Ferguson, J.M., W.W. Weeks, and W.T. Fike. 1988. Production of catnip in North Carolina. Herb Spice Medicinal Plant Dig. 6(4):1-4.

Foster, S. 1993. Herbal renaissance: Growing, using and understanding herbs in the modern world. Gibbs Smith, Salt Lake City.

Galambosi, B. 1993. Introduction of Echinacea purpurea and Leuzea charthanoides into cultivation in Finland. Acta Hort. 331:169-178.

Gulcin, I., O.I. Kufrevioglu, M. Oktay, and M.E. Buyukokuroglu. 2004. Antioxidant, antimicrobial, antiulcer and analgesic activities of nettle (Urtica dioica L.). J. Ethnopharmacol. 90:205-215.

Heeger, E.F. 1956. Handbuch des arznei und gewurzpflanzenbaues. Deutscher Bauernverlag, Berlin.

Herrera, E. 1989. Average freeze-free periods by weather stations during 1982 1987 seasons. New Mexico State Univ. Coop. Ext. Guide H-111.

Johnny's Selected Seeds. 2007. Product ID: 9273 . Chamomile rake. 12 July 2007. <http://www.johnnyseeds.com/catalog/ product.aspx ? category $=292 \&$ subcategory $=$ 313\&item $=9273>$.

Kennedy, D.O., W. Little, C.F. Haskell, and A.B. Scholey. 2006. Anxiolytic effects of a combination of Melissa officinalis and Valeriana officinalis during laboratory induced stress. Phytotherapy Res. 20:96-102.

Koytchev, R., R.G. Alken, and S. Dundarov. 1999. Balm mint extract (Lo-701) for topical treatment of recurring Herpes labialis. Phytomedicine 6:225-230.

Marcin, M.M. 1993. The herbal tea garden: Planning, planting, harvesting and brewing. Storey Communications, Pownal, VT.
Miller, R.A. 1985. The potential of herbs as a cash crop. Acres USA, Kansas City, MO.

Moore, M. 1979. Medicinal plants of the mountain west. Museum of New Mexico Press, Santa Fe, NM.

Moore, M. 1990. Los remedios. Red Crane Books, Santa Fe, NM.

Muller, S.F. and S. Klement. 2006. A combination of valerian and lemon balm is effective in the treatment of restlessness and dyssomnia in children. Phytomedicine 6:383-387.

New Mexico Organic Commodity Commission. 2003. Organic certification handbook. 4 May 2007. <http://nmocc. state.nm.us/pdf/2003NMOCCCRTHand book.pdf>.

New Mexico State University. 1998. New Mexico Climate Center, climate data conversion and data retrieval. 13 Mar. 2007. $<$ http://weather.nmsu.edu/cgi-shl/ cns/uberpage.pl $>$.

Ody, P. 1993. The complete medicinal herbal. New Interlitho, Milan, Italy.

Pedigo, L.P. 1989. Entomology and pest management. Macmillan, New York.

Starman, T.W., T.A. Cerny, and A.J. MacKenzie. 1995. Productivity and profitability of some field-grown specialty cut flowers. HortScience 30:1217-1220.

Sturdivant, L. 1994. Herbs for sale: Growing and marketing herbs, herbal products and herbal know-how. San Juan Naturals, Friday Harbor, WA.

Tyler, V.E. 1994. Herbs of choice. Pharmaceutical Products Press, New York.

U.S. National Arboretum. 2003. USDA Plant Hardiness Zone Map. 20 Dec. 2006. <http://www.usna.usda.gov/ Hardzone/ushzmap.html>.

Weiss, F. 1993. Effects of varied nitrogen fertilization and cutting treatments on the development and yield components of cultivated stinging nettles. Acta Hort. 331:137-142. 